\title{
Apresentação
}

\section{LITERATURA E REPRESSÃO POLÍTICA}

A repressão política se manifesta comumente por meio da perseguição a um indivíduo ou a um grupo dentro da sociedade por razões políticas, particularmente com o propósito de restringir ou impedir sua capacidade de participar da vida política dessa sociedade, reduzindo assim sua atuação entre seus concidadãos.

Amiúde, se manifesta por meio de ações institucionais discriminatórias, como violações de direitos humanos e dos direitos dos cidadãos, proibição da livre expressão (da imprensa e dos indivíduos), abuso da vigilância, brutalidade policial, prisões arbitrárias, julgamentos em tribunais de exceção, assentamentos involuntários, desrespeito, expurgos e ação violenta ou terror. As ações violentas, por sua vez, se manifestam em assassinatos (execuções sumárias), tortura, desaparecimento forçado e outras formas de sanção extrajudicial impostas a ativistas políticos, dissidentes ou a membros da população em geral. A repressão política também pode ser reforçada por meios externos à política estatal, entre eles, comumente participam veículos de comunicação públicos ou privados

Quando sancionada e organizada pelo Estado, a repressão política ganha uma feição própria, comumente denominada de terrorismo de Estado - responsável, ao longo da história, por genocídios, politicídios e outros crimes contra a humanidade.

No Brasil, como em vários outros países, imediatamente depois de períodos de forte repressão política, um certo número de escritores dedicou-se espontaneamente à tarefa de elaborar o passado através da criação artística. Significativamente, a narrativa pareceu ser o meio mais apropriado para tal elaboração. Exatamente sobre essa literatura, trata o volume 11, número 1 da Fólio.

Evidentemente, que o olhar que se volta ao passado jamais poderá empreender um resgate integral de acontecimentos ou eventos que já decorreram. As palavras concebidas pelas imagens daqueles fatos pretéritos se constituem antes como matéria utilizada pelo escritor no seu trabalho de "reconstrução" do passado. Reconstrução sempre balizada por 
interesses do presente e associada às questões práticas do cotidiano.

Para esse dossiê, foram selecionados doze artigos que fomentam o debate sobre a reconstrução do passado que, opressor, continua a assombrar o presente.

O primeiro artigo, "Reescritas da memória — Em câmara lenta de Renato Tapajós: entre o testemunho e a autoficção", escrito por Adriana Aparecida de Figueiredo Fiuza e Rosselane Liz Giordani, discute aspectos ligados à escrita do romance, por meio dos estudos teóricos de Álvarez Fernández, Paul Ricouer e Márcio Seligmann-Silva sobre o testemunho e de Alicia Molero de la Iglesia e Anna Faedrich Martins sobre a autoficção.

Em “As sobrevivências dos signos, a memória involuntária do estrangeiro e o espaço urbano em ruínas", Cacio José Ferreira e Norival Bottos Júnior analisam os quatro primeiros romances de Milton Hatoum, Relato de um certo Oriente (2014), Dois irmãos, (2007), Órfãos do eldorado, (2008), Cinzas do Norte (2012). Os autores defendem a tese de que o romancista faz sobressair não o tema da memória, mas das "sobrevivências das imagens traumáticas, os sintomas da violência, os fantasmas e as sobrevivências de signos".

Fabiano Rodrigo da Silva Santos faz uma leitura do discurso sobre a história, sob o panarama da persistência do tema das ruínas na lírica moderna. Constiuem o corpus de análise os poemas "Ozymandias" (1818), de Percy Shelley; "Le Cygne" (Les fleurs du mal, 1857), de Charles Baudelaire e "Morte das casas de ouro preto" (Claro Enigma, 1951), de Carlos Drummond de Andrade.

A partir do fenômeno do esquecimento e da recuperação da memória histórica na Espanha no pós-franquista, Joyce Rodrigues Ferraz-Infante busca demonstrar, em "Mercedes Núnez Targa: escrever porque se tem de contar", de que forma a narrativa produzida no exílio contribuiu para a recuperação, a preservação e a transmissão da memória histórica relacionada à ditadura do El Generalíssimo Francisco Franco. Como sugerido no título, constitui objeto de análise do artigo a obra da escritora e militante política Mercedes Núnez Targa (1911-1986).

"Fugindo pra outro lugar: o Clube da Esquina, uma poética do movimento", de autoria de Lauro Wanderley Meller, traz um estudo sobre dois discos lançados na década de 1970, Clube da Esquina (1972) e Clube da Esquina 2 (1978), cujas canções manifestam uma poética marcada pela crítica, ainda que indireta, ao regime Militar de 1964.

Marcio Jean Fialho de Sousa e Ilca Vieria de Oliveira assinam o manuscrito "Os diários dizem mais do que pretendem dizer: o caso Lima Barreto". Trata-se de uma análise da escrita íntima de Lima Barreto, que põe em evidência a figura do escritor Lima Barreto como cidadão afrodescendente do Brasil do início do século XX. 
A expressão artística, por meio da qual o personagem Raimundo, do romance CinZas do Norte, de Milton Hatoum, manifesta sua rebeldia e inconformismo com o sistema autoritário do regime militar de 1964, constitui o foco da análise do artigo "A expressão artística como contestação à ditadura militar em Cinzas do Norte, de Milton Hatoum". A autoria é de Márcio Miranda Alves.

Olga Kempinska, no texto “"Minha voz enrouquece’: a metonímia na poesia de Bo- ris Pasternak", analisa a ruptura da fronteira entre arte e vida causada pela simultaneidade de dois fenômenos culturais: a elaboração da dicção futurista e a validação empírica do poder de persuasão dos discursos ideológicos e propagandísticos "no tempo da revolução e da guerra". A coincidência histórica desses dois fenômenos, como defende a autora, fez com que "a linguagem poética passasse a ocupar um lugar incerto, próximo dos discursos da política e da religião".

“A 'Panamérica tropicalista' através da literatura contracultural de José Agrippino de Paula", de autoria de Patrícia Marcondes de Barros, investiga a obra Pan América (1967), do cineasta e dramaturgo José Agrippino de Paula e Silva (1937-2007), publicada no contexto da ditadura militar de 1964 e da contracultura.

Suzeli Santos Santana e Cristiano Augusto da Silva Jutgla analisam o conto "Do- dora", de Bernardo Kucinski, reunido na coletânea Você vai voltar pra mim e outros contos (2014). Publicado bem depois do término do regime repressivo de 1964-1984, a obra apresenta uma feição testemunhal. Como defendem os autores, o conto revisita o contexto da ditadura civilmilitar brasileira, na expectativa de "evitar a perpetuação do autoritarismo de outrora".

Por fim, e considerando Os sertões também uma narrativa de cunho testemunhal, Zelina Márcia Pereira Beato e Szachnowski e Aryadne Bezerra Araújo fazem uma leitura do romance de Euclides da Cunha em que sobressai a "relação traumática entre escri- tor/testemunha e língua na representação do acontecimento traumático do genocídio do povoado de Canudos".

Desejo a todos uma boa leitura!

Márcio Roberto Soares Dias

Editor 